are as cheap as the alternatives. At present, biofuel producers use acids to break down wood waste so that it can be fermented into ethanol, a process that costs about $\$ 1.25$ per gallon. But NREL estimates that its bio-engineered enzymes can reduce that cost to about $\$ .60$ by the end of the decade. At that price, biofuels would be no more expensive than gasoline.

In DOE's solar energy programme, too, science must share the stage with policy and economics. It is not enough, for instance, for solar energy to be technically efficient; it must suit the needs of the electric utilities as well. Most power companies arrange their wiring so that each electric substation serves about two dozen houses. That, it turns out, is just about what a small photovoltaic (PV) facility a half-acre of solar cells - can support. Because the wiring is already in place, NREL technology analysis manager Lynn Coles says that 'grid-connected PV' may be the most painless way for utilities to begin to use solar energy. NREL, along with Pacific Gas and Electric, a California utility, and the Electric Power Research Institute, is planning a trial project.

In September, President Bush officially launched renewable energy's new future by creating NREL - a full-blown national laboratory - out of the old Solar Energy Research Institute. NREL is now starting construction on a new, \$20-million building on land donated by the state of Colorado. But perhaps the surest sign that renewable energy's doldrums are over is NREL's budget - $\$ 125$ million, almost exactly its predecessor's peak in 1980, the last time the renewable future looked as bright.

\title{
A bright light goes out
}

In the renewable-energy doldrums of the 1980 s, one company managed to keep the solar torch alive. Luz International Ltd was not only the world's largest solar energy research and production company, but by the end of the decade it was generating 95 per cent of the world's utility-scale solar electricity, sending an average of $354 \mathrm{MW}$ (enough to power 140,000 households) into the California electric grid.

Then the whole thing fell apart. Last week, Luz filed for bankruptcy. Although its nine electricity-generating facilities will remain, thanks to binding utility commitments, the construction, research and development and financing companies - Luz's future - are no more.

Ironically, the collapse came just as Luz said its solar energy technology was about to become cost-competitive with conventional energy sources, such as coal. Until it halted construction earlier this year, Luz was building the next generation of solar power plant: a facility, known as SEGS $X$, in which rows of mirrored channels would focus sunlight on pipes of oil, heating the oil, which in turn would be used to turn water into steam to drive turbines. Luz predicted that SEGS $X$, planned for completion in 1995, would generate $80 \mathrm{MW}$ at between 6 and 6.5 cents per $\mathrm{kWh}$, somewhere between the cost of natural gas and coal, and less than nuclear plants.

What sank Luz was not bad science, technological hurdles, or bad manage- ment; it was simply politics. In contrast to the oil, gas, coal and nuclear industries, the solar industry has only one lobbyist in Washington. Every year the federal solar tax credits expire, and every year there is doubt until the last minute on whether that lobbyist will be able to get them reinstated. This year, faced with the possibility that it might not have another year of credits, Luz rushed to finish its latest solar plant in about seven and half months. The crash construction schedule put the project more than $\$ 30$ million over budget and wiped out Luz's cash reserves.

Meanwhile, in California, Luz was fighting a losing battle on another front. An error by the state's financial office had mistakenly showed that the company's property tax credits would cost California some $\$ 60$ million. Based on that assessment, the governor vetoed a bill renewing the credits. By the time the mistake was rectified (it turned out that each solar plant would actually generate about $\$ 55$ million in tax revenues for the state over its lifetime), one of the key investors in SEGS $X$ had dropped out. Other investors and banks soon withdrew as well, citing the political and financial uncertainties.

In July, Luz halted construction on SEGS $X$ and laid off most of its employees. Last week it started liquidation procedures to sell off all but the existing solar plants, which will continue to operate under private ownership.

\section{Robbing west to pay east}

\section{Bonn}

ON 22 November the Bundestag approved a 1992 budget for the German research ministry that is 9.7 per cent more than the ministry's 1991 budget. That increase is illusory, however, because with the unification of Germany, the budget must now be spread over a population that is more than 25 per cent larger than before.

The ruling coalition parties of the Christian Democrats and Liberals settled on a budget of DM9,254 million, a figure that the opposition parties rejected as insufficient. The Social Democrats had demanded a budget of at least DM10,000 million, and one Social Democrat, Emil Schnell, said during the debate on the bill that research will be among the losers in German unification.

Research minister Heinz Riesenhuber has referred to the planned spending as a "budget of solidarity" because it will trim funds in western Germany in order to establish a competitive research infrastruc- ture in the east.

Out of the DM9,254-million budget, DM1,300 million will go to pay for research in the new Länder (states), along with an extra DM300 million from the Ministry of Finance. This figure includes DM585 million to establish new institutes out of the institutes of the Academy of Sciences of the former East Germany; of that, DM416 million is allocated to setting up 'blue-list establishments', new national research laboratories and branches of western institutes.

The budget of the Max Planck Gesellschaft will be increased by 8.9 per cent to a total of DM555 million so that it can establish new institutes in eastern Germany; about 10 per cent of its total budget will flow into the east. And the budget of the Fraunhofer Gesellschaft the biggest institution of applied research in Germany - will be increased by 83.9 per cent to DM332 million, with much of the increase set aside for research in the new Länder.

When the budget is broken down by research area, space research and technology shows one of the largest increases for the coming year. The space budget will increase by 12.8 per cent, to DM 1,737 million, despite the fact that Riesenhuber has retreated from some of Germany's obligations to international space collaborations (see Nature 354, 256; 28 November 1991).

Some areas did not fare so well. Particularly hard hit are the 13 national laboratories in the west, which depend on the research ministry for 90 per cent of their budgets and get the rest from the Länder. Riesenhuber froze the budget for these laboratories at the 1991 level-DM2,313 million - until the end of 1994. Cuts were made in coal research and technology (down 16 per cent, to DM122.7 million) and nuclear power (down 4 per cent to DM566.9 million). Although researchers in the east may be pleased, it remains to be seen whether research in the west will be able to thrive under these conditions.

Barbara Bachtler 